\title{
Legal nature of business risk insurance
}

\author{
Aleksei Zolotukhin* \\ Faculty of Law, Russian-Tajik (Slavonic) University, 30 M. Tursunzoda str., Dushanbe, 734025, Tajikistan
}

\begin{abstract}
This paper raises the question of the legal nature of business risk insurance. A conclusion is made that the legal understanding of business risk insurance should be built upon the unity of the actual content of this type of insurance and its legal form. The presence of a special subject on the policy holder's side in business risk insurance determines the features of the object of such type of insurance, which is represented by an entrepreneur's insurable interests related to one's business activity. In the legal sense, insurance is a legal relationship and is characterized by a bilateral connection between the insurer and the policyholder that manifests in a unity of their subjective rights and responsibilities. Two aspects of insurance indicate not the existence of two independent notions free from each other: insurance in the economic sense and insurance in the legal sense, but rather demonstrate two aspects of one phenomenon that exist in an inseparable unity. In the course of comparing business risk insurance and liability insurance, the author comes to a conclusion that unlike liability insurance, business risk insurance is connected not with the policyholder's wrongful behavior but, on the contrary, with the possible dishonesty of their contracting party.
\end{abstract}

\section{Introduction}

Business risk insurance can be considered from two points of view: legal and economic. The economic nature of insurance allows to recognize it as one of the long-familiar categories of socio-economic relations that form during redistribution and exchange of material goods. According to the common opinion, this system of economic relations includes, first, the relations aimed at accumulating a special fund from premiums collected from policyholders and, second, the relations to use this fund to compensate the property damage incurred from natural disasters and other unpredictable adverse events as well as to provide assistance in case of occurrence of different events in the life of policyholders.

The objective nature of economic relations allows to recognize them as relations between subjects of economy related to material and immaterial goods, whose exchange and distribution is carried out by means of money. Such relations lie outside the boundaries of subject-subject relations, there simply is no other subject aside from the society in here. Considering insurance as one of the categories of economic relations indicates the objective nature of these relations, which, while determining the consciousness and will of the persons involved in them, but do not depend on this consciousness and will.

From the legal point of view, business risk insurance represents a legal bond between the insurer and a particular policyholder, characterized by their possession of subjective rights and responsibilities. The very same fact that business risks insurance, according to S.V. Zhuchkov, acts as a mechanism for protecting an entrepreneur from adverse events and their consequences in one's business activity and ensures redistribution of risks [1], illustrates its own economic aspect but not its legal content. This is the way that existing studies in economics [5] describe business risk insurance: as a financial instrument, representing the complex protection of an entrepreneur's insurable interest from the loss events that affect the financial performance of the entrepreneur's business activity, which are manifested in loss of profit, additional expense, and occurrence of loss.

However, the two demonstrated aspects of insurance do not indicate at all the existence of two independent notions free from each other: insurance in the economic sense and insurance in the legal sense. The economic and legal natures of insurance are two sides of the same phenomenon. They can not be considered separately from each other because in their inseparable unity they reflect the true meaning of insurance. The economic nature of insurance can not manifest without the assistance from the legal side of insurance because "the contracts concluded by policyholders act as a legal instrument for attracting funds with the purpose of their mobilization, accumulation, and further use in insurance activities" [3]. In the same way, the legal naturalness of insurance loses its value without its economic sense because economic relations bear the initial, original value for the legal relationship of insurance from the point of view of genesis. Implementation of the economic interest of each policyholder is only attainable

\footnotetext{
*Corresponding author: mczolotoy@ rambler.ru
} 
in the case of unification of as many policyholders as possible, whose insurance premiums form the insurance fund to cover their losses. Such connection between the economic and legal sense of insurance is mainly conditioned by the purpose of serving the public needs that is characteristic of law.

\section{Results and Discussion}

The goals of law are not legal in their nature. "Legal purposes are always but one the lowest links in the chain of the immediate goals pursued by such norms and institutions, and these immediate goals, unlike the legal ones, are material in their nature and possess the economic, political, or other character [4]. When considering one legal institution or another, one should understand that any legal phenomenon is carried out not for the sake of law as such and not because it is a sort of art but rather it comes from the obvious fact that law serves the economy. Law is a superstructure while the economy is the basic phenomenon. The characteristics of economic relations determine what law will be like and law corresponds to the respective level of economic relations.

In this regard, the contractual relations that form between the insurer and the policyholder, as well as the entire civil law, regulate the known social ties for entrenching the wealth to subjects and exchanging material goods and services, thus serving the economic and other needs of the participants of the legal relationships. The first to recognize such kind of interconnection between the economic and legal relations was A.I. Khudiakov, who pointed out that "...the totality of economic relations forming the institution of finance is, at the same time, a certain grouping of social relations that represents the subject of one legal institution or another. Consequently, a legal institution is an economic and financial institution wrapped in a legal "dress"" [5]. The form of legal relationship is given to a broad variety of social connections: economical and technical, organizational, political, family-related, and others. This implies that the legal relationship of insurance, which forms the essence of the legal understanding of insurance, is a legal matter that serves insurance as an economic phenomenon. The legal relationship of insurance is a means of legal pressure upon the actual insurance that is an area of economic phenomena. Given that, the legal form of insurance is also active in its nature. It sort of determines the actual (economic) sense of insurance: those involved in insurance relations perform the actions that they are entitled and must do. Appearing without actual content, the legal form of insurance will in future obtain this content through positive actions by those involved in insurance relations. This achieves the main goal of legal regulation of insurance: the complete formation of actual insurance relations that have not existed before. In case if the behavior of the participants of the legal relationship of insurance departs from the measure of the allowed and required behavior laid out in the subject rights and responsibilities (i.e. breaches the limits of its legal form), such behavior loses the property of legal matter and becomes a wrongdoing.

This way, the appearance of the legal matter of insurance is conditioned by the needs of social development, the needs of the economic basis, and the facts of social reality. But the appearance of particular actual insurance relations requires using legal leverages, which are the legal relationships of insurance. The economic content of insurance represents the implementation of the legal content of the insurance relations.

In other words, insurance in its economic aspect represents the actual economic relations, which means the relations aimed at implementing the economic interests of all subjects of these relations. Such relationships are built outside the "subject-subject" scheme.

In the legal sense, insurance is a legal relationship and is characterized by a bilateral connection between the insurer and the policyholder that manifests in a unity of their subjective rights and responsibilities. Two aspects of insurance indicate not the existence of two independent notions free from each other: insurance in the economic sense and insurance in the legal sense, but rather demonstrate two aspects of one phenomenon that exist in an inseparable unity.

The manifestation of the economic nature of insurance is impossible without the assistance from the legal side of insurance because an insurance policy acts as a legal tool for forming the insurance fund. In a similar way, the legal sense of insurance loses its value without its economic sense because economic relations bear the initial, original value for the legal relationship of insurance from the point of view of genesis: implementation of the economic interest of each policyholder is only attainable in the case of unification of as many policyholders as possible, whose insurance premiums form the insurance fund to cover their losses.

Applying such conclusions to business risk insurance as a particular case of insurance allowed to address it in both legal and economic aspects. From the legal point of view, business risk insurance represents a legal bond between the insurer and a particular policyholder, characterized by their possession of subjective rights and responsibilities. The fact that business risk insurance acts as a mechanism for protecting an entrepreneur from adverse events and their consequences in one's business activity and ensures redistribution of risks, illustrates its own economic aspect but not its legal content.

Business risk insurance should be built upon the unity of the actual content of this type of insurance and its legal form. In this case, the specificity and selfsufficiency of the considered type of insurance relationship determine not only the subjects of the legal relationship and the rights and responsibilities binding them but also the object of such relations.

Speaking of the characteristics of the contracting parties of business risk insurance, it should be noted that the policyholder in such type of insurance, as compared to other types of property insurance, can be represented only by persons undertaking business activities, including sole proprietors and commercial organizations 
as well as nonprofit organizations if insurance is related to their business activity.

The existence of a special subject on the policyholder's side in business risk insurance conditions the features of the object in such type of insurance. In this case, the object of insurance are the insurable interests of an entrepreneur related to one's business activity, in particular, as specified in Part 2 Pt. 3 of the Art. 1015 of the Civil Code of the Republic of Tajikistan, the insurable interests concerned with loss of expected revenue from business activity because of breach of obligations by the counterparty or change of conditions of such activity due to circumstances independent from the entrepreneur. The area of business activity where it is possible to apply a business risk insurance policy is not limited by some legal frameworks, which ensures the insurance protection of many types of economic operations. Due to the fact that each type of business activity has its own inherent forms of business risks, an insurance organization designing its business risk insurance products for one type of enterprise or another must take into account the particular forms of these risks' manifestations. However, as stated by A.A. Slutskii, successful adaptation to specifics is possible only while preserving the basic principles of property insurance, which can not be sacrificed to the trends of demand for insurance products [6].

Due to the mentioned specifics of the considered type of insurance, risks of loss of expected revenue from activities that fall outside the scope of business are not subject to insurance in this case. For example, risks of loss of stock dividends by shareholders (investors) due to loss-making activity of a joint-stock company can not be insured by a business risk insurance policy because the activity of a shareholder (investor) to form the authorized capital of a joint-stock company and investing the capital in production with the purpose of generating revenue, though is a type of revenuegenerating activity, is not a business activity. Risks of such type are financial risks and their nature is independent in relation to business risks.

The existing civil legislation of the Republic of Tajikistan distinguishes business risk insurance as an independent type of general insurance along with property insurance and legal liability insurance (Part 2 Art. 1015 of the Civil Code of the RT, Part 2 Art. 5 of the Law of the RT "On Insurance Business"). Such type of insurance, little-known in the practice of the Republic of Tajikistan, represents a totality of types of insurance that imply the liability of the insurer to pay insurance indemnity to the policyholder in case of occurrence of the loss events that affect the entrepreneur's material and monetary assets and results of business activities, and cause damage, loss of profit and additional expense [7]. Business risk insurance, according to the experts commenting on its statutory regulations, may include the risk of business interruption, risk of non-payment, risk of delay in delivery of goods, and risk of producer's liability for manufacturing products that are dangerous to user and public, including the producer's and seller's liability in terms of the regulations for consumer protection [8].
Specialized studies devoted to business risk insurance attempt to distinguish types of such insurance. For example, S.V. Zhuchkov breaks down business risk insurance into: 1) insurance of loss from contracts of sale of goods, work, services, and other property of an entrepreneur; 2) insurance of term deposits and funds on bank accounts by an entrepreneur; 3) bank's insurance from borrower delinquency; 4) business interruption insurance; 5) insurance of innovations by an entrepreneur; 6) insurance from sales volume reduction, additional expense, and other loss in business activity [9].

We believe that as much as the available research tries to map the typology of business risk insurance, it is simply impossible to work out some exact modifications of such insurance because of the countless number of areas of business, each having its own specific forms of business risk. For this reason, any attempts to build a benchmark layout of such type of insurance products will always be only a basic reference for insurers.

Due to the fact that the object of any kind of general insurance is not the property itself but the interest related to this property, there is a common opinion in legal research that, regardless of the self-sufficiency of business risk insurance, in terms of its object it intersects with other types general insurance, such as property insurance and liability insurance. For example, Yu.B. Fogelson considers that "the object of business risk insurance includes both the interest insured through property insurance contracts and the interest insured through liability insurance contracts" [10], "and since it is not forbidden to insure property (liability) from any risks, including those characteristic of business risk, it becomes clear that in certain cases the policyholder has a choice: to insure one's interest through a business risk insurance contract or through a property (liability) insurance contract" [11]. While discussing the issue of intersection of the object of the abovementioned types of insurance, Yu.B. Fogelson provides examples from legal practice that illustrate serious problems in delimiting general insurance contracts when such contracts are concluded by an entrepreneur [12].

\section{Conclusion}

From our point of view, there is no serious reason to confuse the qualifications of the mentioned types of general insurance. Let us compare, for example, business risk insurance with liability insurance. According to Part 8 Art. 4 of the Law of the RT "On Insurance Business", legal liability insurance represents a totality of types of insurance that imply payment of insurance indemnity in the amount of partial or complete reparation for the loss inflicted to a person's insurable interest related to the person's liability to compensate the loss incurred by the third parties (highlighted by the author, A.Z.). In this case, the object of insurance is the insurable interest related to the risk of policyholder's (the insured person's) loss caused by compensating for the adverse consequences of the policyholder's wrongful behavior within the area of interest of the victim. This way, 
liability insurance is closely connected with the policyholder's wrongful actions towards a third party. Such wrongful actions can be established by the court or other legal authority so that the liability of the policyholder to pay the indemnity appears. This way, the loss event in the liability insurance contract is the fact of assigning the liability to the policyholder.

Unlike this, business risk insurance is connected not with the policyholder's wrongful behavior but, on the contrary, with the possible wrongdoing by the policyholder's counterparties such as, for example, their breach of the terms of the existing contract by failing to perform or unduly performing their contractual obligations. Consequently, the loss event here is the fact of causing loss to the policyholder by the wrongful actions of one's counterparties.

When delimiting the considered types of insurance, $\mathrm{Yu}$.B. Fogelson believes that insurance of property is carried out for the case of the first component of loss (actual loss). Insurance of liability is performed for the case of loss caused by assignment of liability, i.e. for the case of the second component of loss (lost profit), that arise due to particular reasons, namely the assignment of liability. At the same time, business risk insurance is carried out for the case of any loss caused by particular reasons [13]. In our opinion, it is impossible to separate the abovementioned types of insurance by nature of the inflicted loss because the losses described in Part 15 of the Civil Code of both the Republic of Tajikistan and the Russian Federation [14] are very closely related to the wrongdoing itself. According to O.S. Ioffe, loss is a category of legal liability and represents the adverse effects to the area of interest of the victim caused by wrongful behavior [15]. For this reason, both the first and the second components of loss in terms of its understanding in accordance with Part 15 of the Civil Code, are only related to insurance of liability.

\section{References}

1. S.V. Zhuchkov, Legal regulation of business risk insurance in the Russian Federation: dissertation of $P h D$ in Law, (Moscow, 2005)

2. Kh.A. Paragulgov, Risk insurance: dissertation of PhD in Economics, (Moscow, 2006)

3. T.I. Sultonova, Theoretical issues of aleatory contracts in the law of Tajikistan: dissertation of DSc in Law, (Dushanbe, 2014)

4. V.I. Nikitinskii, V.V. Glazyrin, Efficiency of legal norms, (Moscow.: Iuridicheskaia literatura, 1980)

5. A.I. Khudiakov, Basic theory of financial law, (Almaty: Zheti Zhargy, 1995)

6. A.A. Slutskii, Risks of consumer lending: basics of building an insurance system considering the negative experience of ROSNO, Bank Lending, 2 (2007)

7. N.G. Kabantseva, V.A. Larionova, N.A. Zakharova, E.A. Bevziuk, S.A. Slesarev, Commentary to the Law of the RF of 27 November 1992 No. 4015-1 "Concerning the Organization of Insurance in the
Russian Federation". Retrieved from: http: //www.garant.ru

8. V.A. Ershov, A.V. Sutiagin, A.N. Kail, Commentary to the Civil Code of the Russian Federation sorted by article. Prepared for the ConsultantPlus system. Retrieved from: http: www.consultant.ru

9. S.V. Zhuchkov, Legal regulation of business risk insurance in the Russian Federation: dissertation of PhD in Law, (Moscow, 2005)

10. Yu.B. Fogelson, Insurance law: theoretical foundations and practice of application: a monography, (2012)

11. Yu.B. Fogelson, Insurance law: theoretical foundations and practice of application: a monography, (2012)

12. Yu.B. Fogelson, Insurance law: theoretical foundations and practice of application: a monography, (2012)

13. Yu.B. Fogelson, Insurance law: theoretical foundations and practice of application: a monography, (2012)

14. T.E. Abova, A.Iu. Kabalkin, Commentary to the Civil Code of the Russian Federation: in 3 vol., Commentary to the Civil Code of the Russian Federation, Part Two (sorted by article). Vol. 2, (Moscow: Urait publishing house, 2006)

15. O.S. Ioffe, Liability in Soviet civil law, Selected studies: in 3 vol. Vol. 1, Legal relationships in Soviet civil law, (2003) 